\title{
Effects of landscape metrics and land-use variables on macroinvertebrate communities and habitat characteristics
}

\author{
Rui M. Cortes ${ }^{1, *}$, Simone Varandas ${ }^{1}$, Amílcar Teixeira ${ }^{3}$, Samantha Jane Hughes ${ }^{1}$, Marco \\ Magalhães ${ }^{1}$ José Barquín $^{2}$, Mario Álvarez-Cabria ${ }^{2}$ and Diego Fernández ${ }^{2}$ \\ ${ }^{1}$ CITAB, UTAD, Apartado 1013, 5001-811Vila Real, Portugal. \\ 2 Environmental Hydraulics Institute, University of Cantabria. \\ ${ }^{3}$ CIMO, ESA, Instituto Politécnico de Bragança, Campus de Santa Apolónia-Apartado 1172, 5301-855 \\ Bragança, Portugal. \\ *Corresponding author: rcortes@utad.pt
}

Received: 22/6/2010 Accepted: 10/5/2011

\begin{abstract}
Effects of landscape metrics and land-use variables on macroinvertebrate communities and habitat characteristics

The growing number of studies establishing links between stream biota, environmental factors and river classification has contributed to a better understanding of fluvial ecosystem function. Environmental factors influencing river systems are distributed over hierarchically organised spatial scales. We used a nested hierarchical sampling design across four catchments to assess how benthic macroinvertebrate community composition and lower spatial scale habitat descriptors were shaped by landscape and land-use patterns. We found that benthic macroinvertebrate community structure and composition varied significantly from catchment to habitat level. We assessed and identified fractal metrics of landscape descriptors capable of explaining compositional and functional change in the benthic faunal indicators and compared them with the traditional variables describing land use and reach level habitat descriptors within a $1 \mathrm{~km}$ radius of each sampling site. We found that fractal landscape metrics were the best predictor variables for benthic macroinvertebrate community composition, function, instream habitat and river corridor characteristics.
\end{abstract}

Key words: Fractal landscape metrics, land use, macroinvertebrates, habitat, spatial scale.

\section{RESUMEN}

Efecto de las variables métricas del paisaje y de los usos del suelo sobre las características de las comunidades de macroinvertebrados y de los hábitats

El creciente número de estudios que relacionan la biota fluvial, los factores ambientales y la clasificación de los ríos, ha contribuido a comprender el funcionamiento de los ecosistemas fluviales. La organización de los factores ambientales fluviales es entendida, en la actualidad, como una jerarquía de factores con varias escalas espaciales. Para evaluar cómo la composición de los macroinvertebrados bentónicos y las características del hábitat a escala local son afectadas por el uso del paisaje y del suelo, se siguió un diseño de muestreo jerárquico en cuatro cuencas. Hemos verificado que la estructura y composición de las comunidades de macroinvertebrados bentónicos varió significativamente desde la escala de cuenca hasta la del hábitat. Fueron evaluadas e identificadas métricas fractales del paisaje que podrían explicar los cambios en la composición y funcionalidad de la fauna bentónica y se ha comparado también con la influencia de las tradicionales variables de usos del suelo y descriptores del hábitat al nivel del tramo, en un círculo de $1 \mathrm{~km}$ de radio alrededor de cada tramo. Encontramos que las métricas fractales del paisaje fueron las mejores variables predictoras de la composición y funcionalidad de las comunidades de macroinvertebrados y de las características del hábitat en el cauce y del corredor fluvial.

Palabras clave: Métricas fractales del paisaje, usos del suelo, macroinvertebrados, hábitat, escala espacial, tipología. 


\section{INTRODUCTION}

River ecosystems are structured across a strong spatial hierarchy, descending from higher spatial scales, such as ecoregion and catchment, to lower spatial scales, such as reach, habitat and microhabitat (Allan Erickson \& Fay 1997, Lamouroux, Dolédec and Gayraud, 2004). Local, smallerscale abiotic and biotic features are nested within, and therefore constrained and controlled by, successively larger-scale factors that act as environmental filters (Frissell et al., 1986; Poff, 1997; Davies et al., 2000; Allan, 2004a; Hughes et al., 2008). This spatial filtering process shapes biological diversity at a given site, creating a distinct subset from the original pool of potential colonisers that passes through the system of environmental filters, which can include changes due to human intervention (Heino et al., 2002; Boyero, 2003; Bonada et al., 2005; Hughes et al., 2008).

According to Poff (1997), the functional significance of changes detected in macroinvertebrate traits is relative to both qualitative and quantitative habitat conditions located at the lower end of the spatial scale of the environmental filters. For example, energy source type (e.g., allochthonous versus autochthonous input) will influence the trophic group and the foraging mode traits. The quantity of the energy source will influence the relative abundance levels.

Several studies have highlighted the importance of the interactions of higher scale factors, such as geology, climate and landscape-level factors (e.g., land use and vegetation patterns) in shaping the local habitat characteristics and the benthic faunal composition, traits and metrics (Lammert \& Allan, 1999; Joy \& Death, 2004; Hughes et al., 2008). Hughes et al. (2008) found that both the basin level environmental variables (e.g., geology and temperature) and the pressure of changes in land use influenced the macroinvertebrate community composition and metrics in an intermittent Mediterranean river in southern Portugal.

Other studies have emphasised how local scale features, such as ecohydraulics or microhabitat quality (Boyero, 2003; Heino et al., 2004; Mérigoux \& Dolédec, 2004; Sandin \& Johnson, 2004), influence macroinvertebrate abun- dance, metrics and functional feeding groups. Factors considered in these studies ranged from reach scale (e.g., dominant flow type, stream depth/width relationship and riparian composition/structure), to habitat and microhabitat scale (e.g., substrate composition, maximum current velocity and hydraulic stress).

More recent studies have focused on the dependence of local hydromorphological characteristics on catchment level features and land use, especially the suitability of reach or catchment scale vegetation as predictors of in-stream features (Allan, 2004b; Buffagni et al., 2009; Sandin, 2009). However, spatial scale effects are often difficult to interpret, due to the innate complexity of the physical habitat produced by the interaction of many multi-scale environmental variables and the limitations and lack of standardisation between the river habitat assessment methodologies.

These findings highlight the need for integrative habitat assessment strategies that incorporate information from relevant spatial scales (Cortes et al., 2009). These are aspects already incorporated into methodologies proposed in several different field surveys, such as the River Habitat Survey (RHS) and Qualitat del Bosc de Ribera ("QBR" riparian forest quality index) (e.g., Prat et al. 2003, Raven, 1998, Raven et al. 2002). Despite the apparent contradictions and difficulties, consideration of the spatial hierarchy of fluvial ecosystems is crucial for identifying associations between the different spatial levels, allowing habitat features, processes and communities to be linked. Such knowledge is essential for developing appropriate management and monitoring measures (Sandin, 2009) because many effects of human pressure on aquatic habitats are spread over several spatial scales (Hughes et al., 2008).

Using a nested approach, the objectives of this study were to (i) determine how benthic macroinvertebrate community composition and traits are shaped by hierarchically organised landscape patterns and land-use variables, possibly reflecting disturbance; (ii) determine the contribution of different environmental factors observed at different spatial scales; and (iii) assess the dependence of lower spatial scale descriptors of physical habitat and river corridor attributes on 



Figure 1. Location of the 15 study sites along the Olo, Corgo, Pinhão and Tua rivers in the Douro catchment in northern Portugal. Study sites are spread along the longitudinal axis of the main rivers except in the Tua catchment, which was sampled only in the lower section. Localización de los 15 puntos de muestreo en los ríos Olo, Corgo, Pinhão y Tua, todos de la cuenca del Duero, Norte de Portugal. Los puntos de muestreo se encuentran repartidos a lo largo del eje longitudinal del río principal, excepto para la cuenca del Tua, la cual fue sólo muestreada en la sección más baja.

larger surrounding land-use patterns. We analysed higher scale landscape and land-use patterns within a fixed buffer zone around each site and lower scale physical instream habitat assessment data derived from River Habitat Survey (RHS), the official method for assessing Water Framework Directive (WFD) lotic hydromorphological support elements in Portugal and the United Kingdom. All features subject to analysis originated from comparable spatial scales along stream segments. The results from this study should contribute to the future development of river habitat assessment methods by recording spatially relevant information regarding key features that determine community distribution patterns, which can subsequently be applied in river management programmes.

\section{METHODS}

\section{Study Area}

The study area comprises four sub-catchments of the Douro basin, namely the rivers Olo, Corgo,
Pinhão and Tua (Fig. 1, Table 1). All of these rivers are high gradient streams ranging in altitude from $50 \mathrm{~m}$ to $1100 \mathrm{~m}$. The rivers cover a range of conditions, from almost completely pristine areas (the Olo, Pinhão and Tua catchments) to areas affected by agriculture, especially vineyards, in particular the downstream sections of the Corgo and Pinhão. The upstream segments drain maritime pine and oak forests mixed with shrub and grassland areas.

The study sites were distributed along the length of the main river channels with the exception of the Tua catchment, which was only sampled in the lower section (Fig. 1). The streams range from $2^{\text {nd }}$ to $6^{\text {th }}$ order (Strahler classification), flowing through granite and schist bedrocks, resulting in low background conductivity values (20$200 \mu \mathrm{S})$. The principal sources of disturbance include forest fire and consequent soil loss and agricultural non-point diffusepollution in the downstream sections. Only the River Corgo exhibits clear signs of eutrophication from point source contamination of food industry effluents, urban runoff, and wastewater treatment plants (Table 2). 
Table 1. Descriptive data for the sampling sites. Information derived from geographic information systems (GIS), including the presence of human impacts. Información de los puntos de muestreo. Datos obtenidos mediante sistemas de información geográfica (SIG), incluyendo la presencia de impactos humanos.

\begin{tabular}{|c|c|c|c|c|c|c|c|c|c|}
\hline \multicolumn{2}{|c|}{$\begin{array}{l}\text { River/catchment/study } \\
\text { site and study site } \\
\text { code }\end{array}$} & $\begin{array}{l}\text { Stream } \\
\operatorname{order}^{(1)}\end{array}$ & $\begin{array}{c}\text { Mean annual } \\
\text { flow } \\
(\mathrm{mm})^{(2)}\end{array}$ & $\begin{array}{l}\text { Mean annual air } \\
\text { temperature } \\
\left({ }^{\circ} \mathrm{C}\right)^{(3)}\end{array}$ & \begin{tabular}{|c|}
$\begin{array}{c}\text { Mean annual } \\
\text { precipitation } \\
(\mathrm{mm})^{(4)}\end{array}$ \\
\end{tabular} & $\begin{array}{l}\text { Altitude } \\
(\mathrm{m})^{(5)}\end{array}$ & Geology ${ }^{(6)}$ & Land use ${ }^{(7)}$ & $\begin{array}{l}\text { Human impacts } \\
\text { (pressures) }\end{array}$ \\
\hline $\begin{array}{l}\text { Olo/Tâmega/Lamas } \\
\text { d'Olo }\end{array}$ & OL & 2 & 500 & $10.0-12.5$ & $1800-2000$ & 990 & $\begin{array}{l}\text { Schists, } \\
\text { Greywackes }\end{array}$ & $\begin{array}{l}59 \% \text { natural/semi- } \\
\text { natural; } 41 \% \\
\text { extensive } \\
\text { agriculture } \\
\end{array}$ & $\begin{array}{l}\text { Small weirs-water } \\
\text { abstraction for } \\
\text { pasture irrigation }\end{array}$ \\
\hline $\begin{array}{l}\text { Olo/Tãmega/ } \\
\text { Varzigueto }\end{array}$ & $\mathrm{OV}$ & 3 & 550 & $10.0-12.5$ & $1400-1600$ & 720 & Quartzites & \begin{tabular}{|l|}
$93 \%$ \\
natural/semi-natural \\
land; $7 \%$ extensive \\
agriculture
\end{tabular} & $\begin{array}{l}\text { Small weirs-water } \\
\text { abstraction for } \\
\text { pasture irrigation } \\
\text { and leisure } \\
\text { activities }\end{array}$ \\
\hline Olo/Tâmega/Tejão & OT & 4 & 700 & $12.5-15.0$ & $1400-1600$ & 220 & $\begin{array}{l}\text { Schists, } \\
\text { Greywackes }\end{array}$ & $\begin{array}{l}86 \% \text { natural/semi- } \\
\text { natural; } 14 \% \\
\text { extensive } \\
\text { agriculture }\end{array}$ & $\begin{array}{l}\text { Small weirs for } \\
\text { water } \\
\text { abstraction-pasture } \\
\text { irrigation and } \\
\text { leisure activities }\end{array}$ \\
\hline Corgo/Zimão & $\mathrm{CZ}$ & 3 & 400 & $12.5-15.0$ & $1200-1400$ & 670 & Granites & $\begin{array}{l}80 \% \text { agriculture; } \\
<18 \% \\
\text { natural/semi- } \\
\text { natural; } 2 \% \\
\text { urban }\end{array}$ & $\begin{array}{l}\text { Untreated urban } \\
\text { effluent }\end{array}$ \\
\hline Corgo/Benagouro & $\mathrm{CB}$ & 3 & 400 & $12.5-15.0$ & $1000-1200$ & 520 & Granites & $\begin{array}{l}82 \% \text { natural/semi- } \\
\text { natural; } 18 \% \\
\text { extensive } \\
\text { agriculture }\end{array}$ & \\
\hline Corgo/Flores & $\mathrm{CF}$ & 3 & 350 & $12.5-15.0$ & $1000-1200$ & 420 & Granites & \begin{tabular}{|l|}
$46 \%$ extensive \\
agriculture; $22 \%$ \\
natural/semi- \\
natural; $32 \%$ \\
urban \\
\end{tabular} & \\
\hline $\begin{array}{l}\text { Corgo/S. M. } \\
\text { Penaguião }\end{array}$ & CSM & 4 & 250 & $15.0-16.0$ & $700-800$ & 100 & $\begin{array}{l}\text { Schists, } \\
\text { Greywackes }\end{array}$ & \begin{tabular}{|l|}
$96 \%$ extensive \\
agriculture (mostly \\
vineyards); $4 \%$ \\
natural/semi-natural \\
\end{tabular} & $\begin{array}{l}\text { Seasonal discharge } \\
\text { from wineries }\end{array}$ \\
\hline Sordo/Corgo/Quintã & CQ & 3 & 400 & $10.0-12.5$ & $2000-2500$ & 700 & $\begin{array}{l}\text { Aluvial } \\
\text { deposits }\end{array}$ & $\begin{array}{l}58 \% \text { intensive and } \\
\text { extensive } \\
\text { agriculture; } 40 \% \\
\text { natural/semi- } \\
\text { natural; } 2 \% \text { urban } \\
\text { area } \\
\end{array}$ & \\
\hline $\begin{array}{l}\text { Tanha/Corgo/ } \\
\text { Passagem }\end{array}$ & $\mathrm{CP}$ & 4 & 350 & $12.5-15.0$ & $800-900$ & 520 & $\begin{array}{l}\text { Schists } \\
\text { Greywackes }\end{array}$ & $\begin{array}{l}72 \% \text { natural/semi- } \\
\text { natural; } 41 \% \\
\text { extensive } \\
\text { agriculture and } \\
\text { pasture }\end{array}$ & \\
\hline Pinhão/Balsa & PB & 4 & 350 & $12.5-15.0$ & $900-1000$ & 540 & $\begin{array}{l}\text { Schists, } \\
\text { Greywackes }\end{array}$ & $\begin{array}{l}82 \% \text { natural/semi- } \\
\text { natural; } 11 \% \\
\text { agriculture } \\
\text { (intensive, } 6 \% \text { and } \\
\text { extensive } 5 \% \text { ) }\end{array}$ & \\
\hline $\begin{array}{l}\text { Pinhão/Vale de } \\
\text { Mendiz }\end{array}$ & PVM & 4 & 350 & $15.0-16.0$ & $600-700$ & 160 & $\begin{array}{l}\text { Schists, } \\
\text { Greywackes }\end{array}$ & \begin{tabular}{|l|}
$97 \%$ extensive \\
agriculture (mostly \\
vineyards); $3 \%$ \\
natural/semi-natural \\
\end{tabular} & \\
\hline $\begin{array}{l}\text { Pinhão/ } \\
\text { Monim }\end{array}$ & PM & 2 & 350 & $12.5-15.0$ & $800-900$ & 490 & Granites & $\begin{array}{l}74 \% \text { natural/semi- } \\
\text { natural; } 26 \% \\
\text { extensive } \\
\text { agriculture and } \\
\text { pasturing }\end{array}$ & \\
\hline Tua/Brunheda & TB & 5 & 250 & $15.0-16.0$ & $600-700$ & 160 & Granites & $\begin{array}{l}93 \% \text { natural/semi- } \\
\text { natural; } 7 \% \\
\text { extensive } \\
\text { agriculture }\end{array}$ & $\begin{array}{l}\text { Seasonal discharge } \\
\text { from olive oil } \\
\text { refineries }\end{array}$ \\
\hline Tua/Foz Tua & $\mathrm{TF}$ & 6 & 125 & $15.0-16.0$ & $600-700$ & 130 & Granites & $\begin{array}{l}75 \% \text { extensive } \\
\text { agriculture (mostly } \\
\text { vineyards); } 25 \% \\
\text { natural/semi-natural }\end{array}$ & $\begin{array}{l}\text { Seasonal discharge } \\
\text { from olive oil } \\
\text { refineries }\end{array}$ \\
\hline Tinhela/Tua/Carlão & TC & 5 & 250 & $15.0-16.0$ & $600-700$ & 170 & $\begin{array}{l}\text { Schists, } \\
\text { Greywackes }\end{array}$ & \begin{tabular}{|l|}
$95 \%$ extensive \\
agriculture (mostly \\
vineyards); $5 \%$ \\
natural/semi-natural \\
\end{tabular} & \\
\hline
\end{tabular}

(1) Strahler system; (2)(3) Portuguese Environmental Agency (1974); (4) Suzanne Daveau (1977); (5) measured from 1:25000 topographic maps;

(6) Portuguese Environmental Agency (1982); ${ }^{(7)}$ Corine Land Cover $(1990,2000)$. 


\section{Biological characterisation}

A hierarchical nested design was used for sampling benthic macroinvertebrate communities at 15 sites across the four catchments to capture the typological gradients and assess how factors related to changes in land use have modified the physical and biological components of the rivers across the study sites (see Heino, Louhi and Muotka, 2004). At each site, we defined three transects with 3 microhabitats (replicates) within each transect. The macroinvertebrate communities were sampled at the same sites and at the same time of year (May/June) in 2006 and 2007 using a Surber sampler $(20 \times 20 \mathrm{~cm}$ frame $)$ randomly located along the transects. A total of 270 samples were collected and sorted in the laboratory. Organisms were preserved in $70 \%$ ethanol and identified to genus level for most taxonomic families (except Diptera and Oligochaeta).

To assess the relationship between the environmental variables and the benthic fauna, macroinvertebrate community composition, metrics and trait data were used to determine the most suitable approach for identifying the effects of land use on the aquatic biota. Traits express the adaptation of an organism to the surrounding conditions (e.g., respiration, locomotion or trophic group), providing additional information regarding the effect of environmental changes on river biota and ecosystem function.

\section{Environmental characterisation}

We used environmental variables from landscape and reach levels of observation. Landscape and

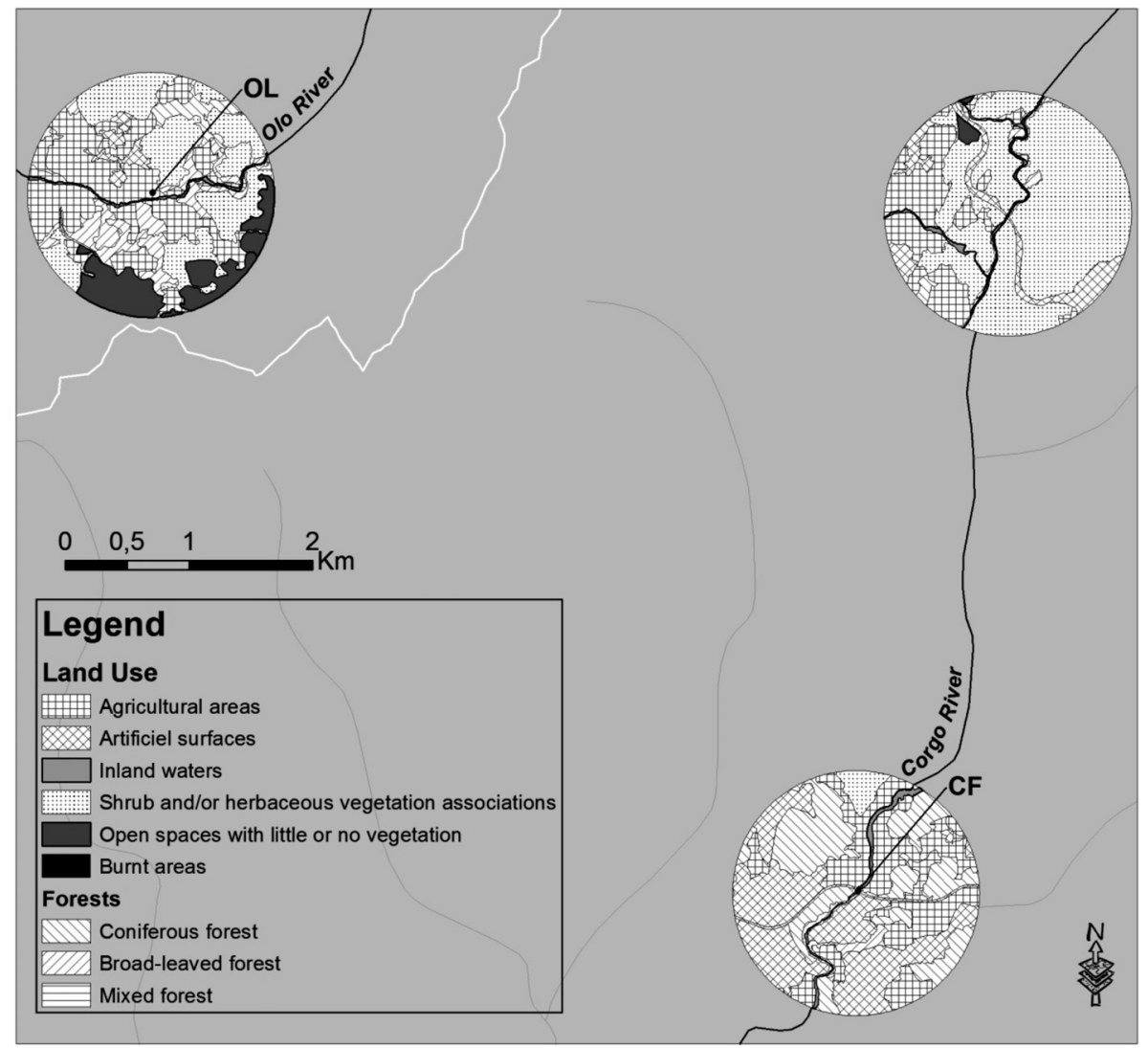

Figure 2. Characterisation of the different river sites for fractal metrics and land-use variables. A circle with a radius of $1 \mathrm{~km}$ was defined around each sampling site to characterise and quantify the fractal and land-use variables. Caracterización de los diferentes puntos de muestreo para las variables uso del suelo y las métricas fractales. En torno a cada punto de muestreo se definió un círculo de un kilómetro de radio para caracterizar y cuantificar las variables fractal y uso de la suelo. 
land-use data were obtained from Corine Landcover. Several authors (e.g., Hawkins \& Vinson, 2000; Sandin \& Johnson, 2000; Pyne et al., 2007) have mentioned the absence of strong associations between environmental descriptors at higher spatial scales and local aquatic communities, due to the high levels of heterogeneity within each land cover classification type. To overcome this potential limitation, we used a proximity method, defining a circle with a radius of $1 \mathrm{~km}$ around each site (Fig. 2).

We applied fractal and non-fractal metrics to the landscape data. Fractal metrics describe the size, shape and interspersion of patches, which are essentially individual polygons or contiguous sets of cells. Non-fractal metrics describe the relative proportions of different classes/land uses, i.e., they group patches together that share the same attribute. Six fractal metrics were applied to each of the eight types of land use defined, giving a total of 48 variables (Table 2). The River Habitat Survey methodology was used to record reach scale physical habitat characteristics (RHS; Raven et al., 1997, Raven et al. 1998). The STAR project (Furse et al, 2006), which analysed the interaction of different biological quality elements (macroinvertebrates, macrophytes, diatoms, fish, hydro-morphology and chemistry) over a wide geographical range and between stream types, also used RHS for preliminary testing of links between selected invertebrates metrics and modification in rivers. These results indicated that selected macroinvertebrate metrics were highly correlated with features recorded by RHS (Erba et al, 2006). For these reasons, and because RHS is the selected methodology for assessing WFD lotic hydromorphological support elements in Portugal, we applied this methodology in the field.

RHS assesses habitat quality over a $500 \mathrm{~m}$ reach and within a $50 \mathrm{~m}$ buffer on each bank. Features such as channel substrate, flow type, habitat features, aquatic vegetation types, bank vegetation structure and artificial modifications were recorded at 10 transects ("spot checks") at $50 \mathrm{~m}$ intervals along the $500 \mathrm{~m}$ reach. Observations ("sweep up") were also made along the $500 \mathrm{~m}$ reach to include features not described at each spot-check (e.g., counts of natural and man-made features or riparian vegetation). RHS also records hydromorphological measurements taken at a representative cross-section of the $500 \mathrm{~m}$ reach and the presence of key taxa.

RHS data were used to derive two indices, namely, the Habitat Quality Assessment (HQA) and the Habitat Modification Score (HMS). The HQA comprises the sum of scores of 9 sub-indices covering physical habitat, vegetation

Table 2. Environmental descriptors used for describing fractal metrics, land use and habitats at each of the 15 sites included in the rivers Olo, Corgo, Pinhão and Tua, The six fractal metrics were applied to each of the 8 different use types, resulting in a total of 48 fractal variables. Descriptores ambientales utilizados para caracterizar el paisaje, los usos del suelo y los hábitats de cada uno de los 15 puntos de muestreo de los ríos Olo, Corgo, Pinhão y Tua. Las 6 métricas fractales del paisaje fueron derivadas de cada uno de los 8 distintos usos del suelo, resultando en un total de 48 variables del paisaje.

Fractal metrics

Land use variables

Agriculture, except vineyards (area in $\mathrm{m}^{2}$ and $\left.\%\right)-(\mathrm{AG})$

Vineyards (area in $\mathrm{m}^{2}$ and \%) - (VIN)

Coniferous woodland (area in $\mathrm{m}^{2}$ and $\left.\%\right)-(\mathrm{CW})$

Broadleaf woodland (area in $\mathrm{m}^{2}$ and $\left.\%\right)-(\mathrm{BL})$

Mixed woodland area (area in $\mathrm{m}^{2}$ and \%) - (MW)

Urban area (area in $\mathrm{m}^{2}$ and $\left.\%\right)$ ) - (URB)

Scrub \& shrubs (area in $\mathrm{m}^{2}$ and $\%$ ) - (SHR)

Water surface including reservoirs and wetlands (area in $\mathrm{m}^{2}$ and $\left.\%\right)-(\mathrm{WA})$
Habitat descriptors
Artificial features

Habitat Modification Score (HMS)

Habitat quality

HQA flow

HQA channel

HQA bank features

HQA bank vegetation structure

HQA point bars

HQA in-stream channel

vegetation

HQA land use

HQA trees

HQA special features 
cover, hydrodynamic characteristics of the river channel and adjacent land use. The HMS quantifies the extent of modification (e.g., the presence of weirs, bank protections, water diversions and abstractions) along the channel (Table 2).

Slight modifications, such as key taxa and types of human modification, were introduced to the RHS methodology to account for the geographical location. RHS was carried out at each site the same time as the biological inventories during the first year; we assumed RHS characteristics remained unchanged in the $2^{\text {nd }}$ year. The environmental descriptors were taken from the sub-indices derived from the RHS data that contribute to the final score of the HQA index and the HMS (Table 2).

\section{Statistical Analysis}

Prior to all analyses, a non-redundant subset of landscape parameters was derived to avoid multicollinearity. Redundant environmental and pressure parameters were removed using the Spearman Rank Correlation analysis method (Hering et al., 2006a, c; Feld \& Hering, 2007). If two environmental or pressure variables were highly correlated (with a threshold value of $r \geq 0.7$ ) the variable with a higher overall mean correlation coefficient was excluded from further analysis.

We performed a nested permutational multivariate analysis of variance (MANOVA) using a reduced Bray Curtis Coefficient based model to analyse the dependence of the biological assemblages upon the three spatial levels of observation, namely, the basin, mesohabitat and microhabitat. All of the spatial levels were considered to be fixed factors. MANOVA calculates the pseudo-F statistic, which is equivalent to the original $\mathrm{F}$ statistic in traditional ANOVA but does not have a known distribution under a true null hypothesis.

Following MANOVA analyses, we determined the principal environmental factors contributing to change in the macroinvertebrate community structure at each spatial scale by running three separate multiple non-parametric regressions from distance-based linear models (DISTLM) between macroinvertebrate taxa (dependent variables; genus level data of taxa occurring at $\leq 2$ sampling sites were excluded) and RHSderived habitat quality sub-indices, land-use variables and fractal metrics (independent variables; see Table 2). Following the regression analyses, Akaike's information criterion (AIC; Akaike 1973, Akaike 1974) was used to extract the variables that significantly increased the amount of explained variation, thereby optimising the global AIC.

Distance-based redundancy analysis (dbRDA) was computed with the benthic faunal metrics sensitive to contamination, land use and fractal metrics to determine how fractal patterns and disturbance shaped river function as described by the macroinvertebrate traits. As with DISTLM,

Table 3. Invertebrate metrics and their acronyms, selected from Varandas \& Cortes (2009) and derived from the benthic invertebrate communities sampled in 15 sites of the rivers Olo, Corgo, Pinhão and Tua in northern Portugal in 2006 and 2007. Listado de métricas de invertebrados y los acrónimos seleccionados por Varandas \& Cortes (2009) derivados de las comunidades de invertebrados bentónicos muestreadas en 15 puntos de los ríos Olo, Corgo, Pinhão y Tua, en el norte de Portugal, en 2006 y 2007.

\begin{tabular}{|c|c|}
\hline Invertebrate community metrics & Codes \\
\hline Families of Ephemeroptera, Plecoptera, Trichoptera & fEPT \\
\hline Families of Predators & $\mathbf{f P}$ \\
\hline Families of gatherers & fGath \\
\hline Genus of shredders & gShr \\
\hline Genus of filterers & gFil \\
\hline Families of swimmers & fSwi \\
\hline Families of clingers & fCling \\
\hline Index IBMWP' & IBMWP \\
\hline Index FBI & FBI \\
\hline Percentage of intolerants & $\%$ Int \\
\hline Percentage of limnophilous & $\% \operatorname{Lim}$ \\
\hline Percentage of rheophilous & \% Rhe \\
\hline Percentage of shredders & $\% \mathrm{Shr}$ \\
\hline Percentage of scrapers & $\%$ Scr \\
\hline Percentage of filterers & $\%$ Fil \\
\hline Percentage of gatherers & \% Gath \\
\hline Percentage of predators & $\%$ Pred \\
\hline Percentage of omnivorous & $\%$ Omn \\
\hline Percentage of parasites & \% Par \\
\hline Percentage of organisms with aerial respiration & $\%$ ar \\
\hline Percentage of organisms with branchial respiration & $\%$ br \\
\hline Percentage of organisms with cutaneous respiration & $\%$ cr \\
\hline $\begin{array}{l}\text { Percentage of organisms with branchial and aerial } \\
\text { respiration }\end{array}$ & \% bar \\
\hline $\begin{array}{l}\text { Percentage of organisms with branchial and } \\
\text { cutaneous respiration }\end{array}$ & $\%$ bcr \\
\hline Percentage of organisms with pulmonary respiration & $\%$ pr \\
\hline
\end{tabular}


Table 4. Comparison of hierarchical MANOVA $(*=P<0.05)$ results detecting differences in benthic communities between catchments, sites and transects at 15 sites sampled in the rivers Olo, Corgo, Pinhão and Tua in northern Portugal in 2006 and 2007. Comparación de los resultados de los MANOVA jerárquicos $(*=\mathrm{P}<0.05)$ de las comunidades de invertebrados bentónicos entre cuencas, sitios y transectos en los 15 puntos de muestreo de los ríos Olo, Corgo, Pinhão y Tua, en el norte de Portugal, en 2006 y 2007.

\begin{tabular}{lcccc}
\hline Source of variation (2006) & Df & Mean squares & Pseudo-F & P \\
\hline Basin & 3 & 16625 & 1.482 & $\mathbf{0 . 0 4 4 ^ { * }}$ \\
Mesohabitat & 11 & 11157 & 5.415 & $\mathbf{0 . 0 0 1 *}$ \\
Microhabitats & 30 & 2062 & 1.439 & $\mathbf{0 . 0 0 1 *}$ \\
Residual & 90 & 1433 & & $\mathbf{P}$ \\
Source of variation (2007) & Df & Mean squares & Pseudo-F & 0.115 \\
Basin & 3 & 11771 & 4.290 & $\mathbf{0 . 0 0 1 *}$ \\
Mesohabitat & 11 & 9122 & 1.065 & 0.182 \\
Microhabitats & 30 & 1178 & & \\
\hline
\end{tabular}

dbRDA uses a multivariate multiple regression, but it is based upon a principal coordinates ordination of biological data axes (based on a similarity matrix using Euclidean distances) on predictor variables (the environmental descriptors). We used biological metrics identified as the most sensitive to disturbance in catchments in northern Portugal (Table 3; Varandas \& Cortes 2009). The benthic data were log-transformed, and the environmental data were standardised to the unit of variance (land use and fractal variables, except the RHS habitat indices). Multivariate analyses were performed using the package PERMANOVA for PRIMER (Anderson \& Gorley, 2008).

Finally, the degree of dependence of the lower spatial scale descriptors, namely, physical habi-

Table 5. Multiple non-parametric regressions obtained by distance-based linear models between benthic invertebrate communities, habitat indices, land use and fractal metrics. Akaike's information criterion (AIC) was used to select the most significant group of variables. Because the regressions with the fractal metrics selected 13 variables, only the groups of variables leading to the lowest AIC, ranked according to their importance, are displayed. Models, 1, 2 and 3 used 10, 8 and 48 predictor variables, respectively. Resultados obtenidos de la regresión múltiple no-paramétrica basada en modelos lineales de distancias entre las comunidades de invertebrados bentónicos, índices de hábitat, usos del suelo y métricas fractales del paisaje. Se utilizó el de información de Akaike (AIC) para seleccionar el grupo de variables más significativo. Dado que las regresiones con las métricas fractales del paisaje seleccionaron 13 variables, sólo se incluyeron aquellas que llevaron a un menor AIC según su importancia. Modelos, 1, 2 y 3, usaron respectivamente, 10,8 y 48 variables predictivas.

MODEL 1 with Habitat quality (RHS) indices; $R^{2}=0.218$

\begin{tabular}{|c|c|c|c|}
\hline Variables selected (Best model 2 var.) & AIC & Pseudo-F & $\mathbf{P}$ \\
\hline HQA flow type & 109.60 & 1.22 & 0.269 \\
\hline HQA vegetation channel & 109.26 & 2.03 & 0.380 \\
\hline \multicolumn{4}{|c|}{ MODEL 2 with Land use variables; $R^{2}=0.313$} \\
\hline Variables selected (Best model 2 var.) & AIC & Pseudo-F & $\overline{\mathbf{P}}$ \\
\hline Agriculture area & 107.75 & 3.09 & $0.04 *$ \\
\hline Broadleaf woodland & 107.31 & 2.12 & 0.22 \\
\hline \multicolumn{4}{|c|}{ MODEL 3 with Fractal metrics; $R^{2}=0.978$} \\
\hline Variables selected (Best model 13 var.) & AIC & Pseudo-F & $\mathbf{P}$ \\
\hline Area weighted patch fractal dimension of agriculture & 106.93 & 4.00 & $0.01 *$ \\
\hline Total edge broadleaf forest & 106.19 & 2.40 & 0.05 \\
\hline Patch size standard deviation of mixed forest & 105.98 & 1.75 & 0.11 \\
\hline Number of patches of vineyard & 105.22 & 2.01 & $0.02 *$ \\
\hline Mean fractal dimension area patch -broadleaf woodland & 104.63 & 1.70 & 0.07 \\
\hline Number of agricultural patches & 103.51 & 1.85 & 0.07 \\
\hline Area weighted patch fractal dimension of mixed forest & 101.24 & 2.30 & $0.03 *$ \\
\hline
\end{tabular}


tat and river corridor attributes, on the surrounding larger scale environmental conditions was also assessed using DISTLM between the RHS indices (HQA and HMS), the fractal metrics and the land-use factors.

\section{RESULTS}

The MANOVA results revealed several significant associations (Table 4; $P<0.05$ ) between spatial hierarchy (i.e., independent factors of basin, mesohabitat and microhabitats) and the benthic macroinvertebrate assemblage (the dependent factor). Significant associations were identified across all spatial scales for the first sampling year (2006), especially at the lower spatial scales of mesohabitat and microhabitats. The only statistically significant association detected in the second year (2007) was at the mesohabitat level (Table 4). The results clearly show interannual variation in the statistical strength of these associations ( $p<0.05)$.



The results of the multiple non-parametric regressions from the distance-based linear models (DISTLM) between the macroinvertebrate taxa and the hierarchically organised variables of habitat quality (Table 5) clearly highlighted how fractal metrics (particularly the fractal dimensions of broadleaf forest, agricultural patches and the number of vineyard patches; $p<0.05$ ) and land use (agriculture; $p<0.05$ ) appear to strongly shape benthic composition when compared with RHS descriptors of habitat quality $\left(R^{2}=0.978\right.$ for the fractal metrics, $R^{2}=0.313$ for land use and $R^{2}=0.218$ for the RHS indices; Table 5). However, care must be taken in interpreting these results by directly comparing the $R$ values because each model used a different numbers of predictors. The larger number of variables in the final model, for example, contributed to the higher $R^{2}$ value for this analysis.

The dbRDA ordination for the fractal metrics (Fig. 3) revealed groupings of sites and macroinvertebrate metrics along axes 1 and 2 . The sites

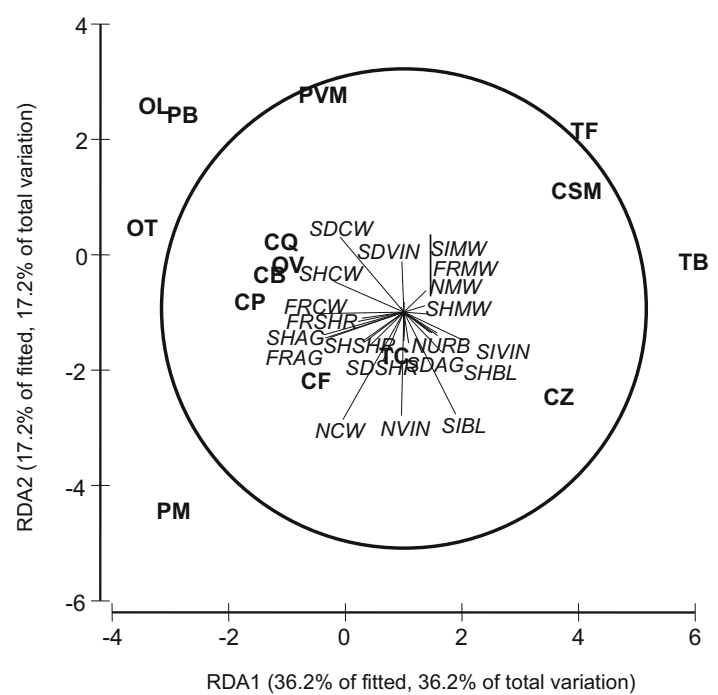

Figure 3. Redundancy analysis (dbRDA) between invertebrate metrics (left) and fractal metrics (right; groups of environmental parameters with low representation were excluded from the analysis). The fractal metric codes are $\mathbf{N}=$ number of patches, $\mathbf{S D}=$ patch size standard deviation, $\mathbf{S I}=$ mean shape index, $\mathbf{S H}=$ mean patch fractal dimension, $\mathbf{F R}=$ area weighted mean patch fractal dimension. The vegetation types are VIN = vineyard; $\mathbf{A G}=$ agriculture; $\mathbf{B L}=$ broadleaf woodland; $\mathbf{C W}=$ coniferous woodland; $\mathbf{M W}=$ mixed woodland and URB = urban area (see Table 2 for the biological metric codes). Análisis de redundancia (dbRDA) entre las métricas de invertebrados (gráfico de la izquierda) y las métricas del paisaje (gráfico de la derecha. Se excluyeron del análisis los parámetros ambientales con una baja representación). Las primeras letras de los acrónimos utilizados indican: $\boldsymbol{N}=$ número de parcelas, $\boldsymbol{S D}=$ desviación estándar del tamaño de la parcela, $\boldsymbol{S I}=$ índice de la forma media, $\boldsymbol{S H}=$ dimensión fractal media de la parcela, $\boldsymbol{F R}$ = área corregida por la dimensión fractal media de la parcela, mientras que las últimas letras representan tipos de vegetación: $\boldsymbol{V I N}=$ viñedos; $\boldsymbol{A} \boldsymbol{G}=$ agricultura $; \boldsymbol{B L}=$ bosque de caducifolias; $\boldsymbol{C} \boldsymbol{W}=$ bosque de coníferas; $\boldsymbol{M W}=$ bosque mixto y $\boldsymbol{U R \boldsymbol { B }}=$ área urbana (mirar Tabla 2 para los códigos de las métricas biológicas). 
from the rivers Corgo and Tua were clearly separated from remaining sites along axis 1 , whereas sites on the River Olo were separated along axis 2. The sites in the upper left quadrant (all of the River Olo sites and two sites along the River Pinhão) were grouped according to fractal metrics describing properties of coniferous woodland and macroinvertebrate metrics describing a greater percentage of shredders, scrapers and cutaneous or branchial modes of respiration. The increased percentage of intolerant macroinvertebrates and the higher FBI index values indicated the presence of essentially stenobiontic organisms. Sites in the lower left hand quadrant (from the River Tua, River Corgo and the River Pinhão) were predominantly characterised by agricultural fractal metrics and macroinvertebrate metrics describing trophic traits (e.g., genera of shredders, genera of filterers, families of gatherers, and families of predators) and habit or locomotion (e.g., families of clingers and families of swimmers). Higher values for the IBMWP and the EPT metrics also occurred at these sites. The sites in the upper right-hand quadrant (from the Rivers Tua and Corgo) were characterised by fractal metrics of mixed woodland with lower values of the biological metrics and traits previously described. The single site in the lower right quadrant (from the River Corgo (CZ)), separated along both axes 1 and 2, was of low quality with a mixture of fractal metrics describing a highly fragmented landscape consisting of vineyards, urban areas, agriculture and broadleaf woodlands.

The macroinvertebrate metrics and traits described the presence of filter-feeders, branchial/ cutaneous and pulmonary respiration and a predominance of gatherers. The lack of any strong gradient associated with the fractal metrics in the ordination space, revealed by the short length of the associated arrows, suggests that the level of explained variation was evenly divided between them.

The land-use dbRDA ordination (Fig. 4) revealed shifts along axis 1 from sites associated with urban and shrub-scrub land use to those associated with agricultural land use and the presence of reservoirs or wetlands. The notable shift in land-use along axis 2 was from coniferous woodland to broadleaf woodland. Far higher levels of variation were explained along the first axis in the land-use dbRDA (73.9\%) compared with the fractal metric dbRDA (36.2\%), but similar levels of variation were explained along the sec-
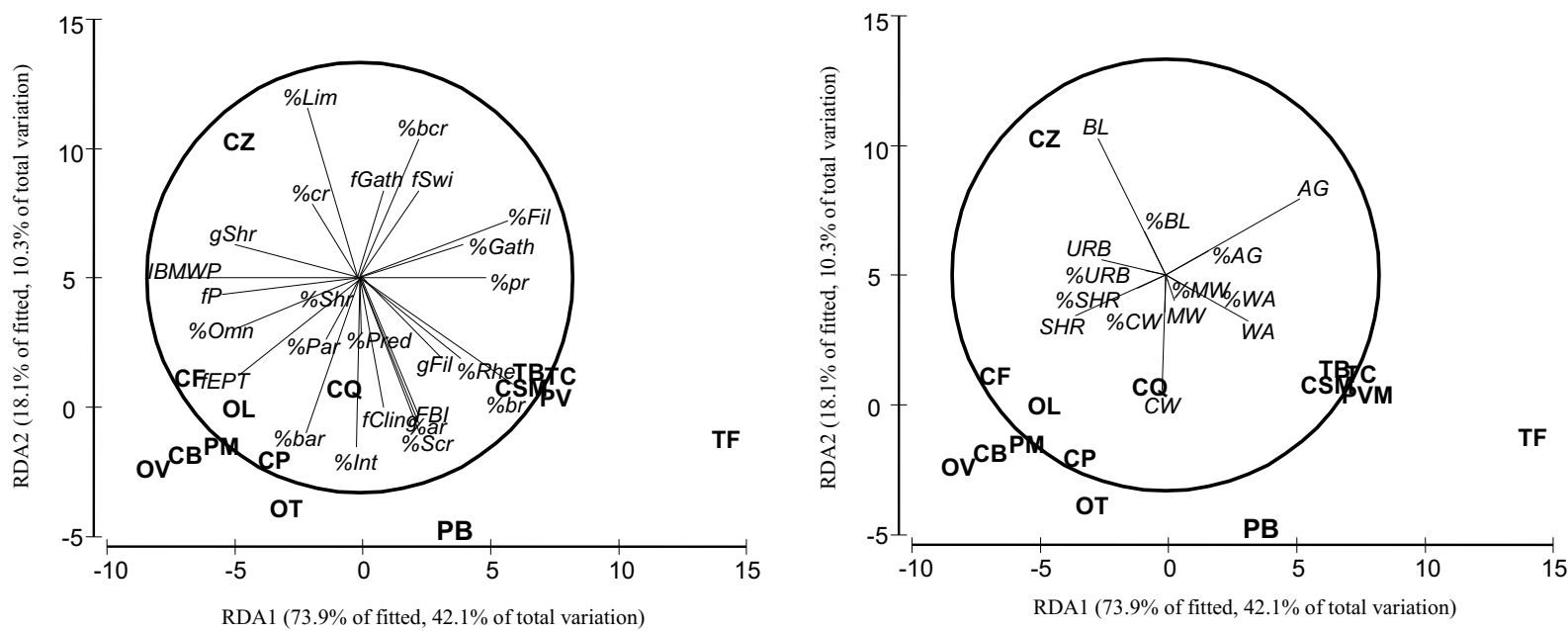

Figure 4. Redundancy analysis (dbRDA) between invertebrate metrics (left) and land use (right; groups of environmental parameters with low representation were excluded from the analysis). $\mathbf{A G}=$ agriculture; $\mathbf{B L}=$ broadleaf woodland; $\mathbf{C W}=$ coniferous woodland; $\mathbf{M W}=$ mixed woodland; $\mathbf{U R B}=$ urban area and $\mathbf{W A}=$ water surface including reservoirs and wetlands (see Table 2 for the biological metric codes). Análisis de redundancia (dbRDA) entre las métricas de invertebrados (gráfico de la izquierda) y las los usos del suelo (gráfico de la derecha; los parámetros ambientales con una representación pequeña fueron excluidos del análisis). Los acrónimos utilizados fueron: $\boldsymbol{A} \boldsymbol{G}=$ agricultura; $\boldsymbol{B} \boldsymbol{L}=$ bosque de caducifolias; $\boldsymbol{C W}=$ bosque de coníferas; $\boldsymbol{M W}=$ bosque mixto; $\boldsymbol{U R \boldsymbol { R }}$ = área urbana e $\mathbf{W A}=$ aguas superficiales incluyendo balsas y humedales (ver códigos de las métricas biológicas en la Tabla 2). 
ond axis of each analysis ( $18.1 \%$ for the land-use dbRDA, $17.2 \%$ for the fractal dbRDA).

The marked IBMWP gradient along axis $1 \mathrm{did}$ not appear to be strongly matched with any particular type of land use, although stronger associations could be detected with the fEPT metric and the presence of shrub-scrub. The strongest associations in the ordination space were between broadleaf woodland and the presence of higher numbers of cutaneous respiring organisms, agricultural woodland and the presence of greater numbers of filterers and gatherers and coniferous woodland and the presence of greater numbers of intolerant organisms and branchial and aerial modes of respiration. As seen previously, the site $\mathrm{CZ}$ on the River Corgo was isolated in the ordination space and was associated with broadleaf woodland land use but with no particular macroinvertebrate metric or trait. Macroinvertebrate traits and metrics expressed as percentages tended to exhibit slightly stronger gradients in the land-use ordination space. This pattern was not apparent in the fractal metric based dbRDA.

Multiple regressions were computed to assess the dependence of lower spatial scale descriptors of the physical habitat and river corridor on larger surrounding land patterns of fractal metrics versus land use (Table 6). The results indicated an overall statistically stronger influence of the fractal metrics compared with the land-use variables ( $R^{2}=0.992$ and $R^{2}=0.388$, respectively) on the lower spatial descriptors, highlighting the importance of adequate fractal pattern characterisation in data sets. Again, caution should be exercised when comparing the $R^{2}$ values. Despite predominantly non-significant $\mathrm{P}$ values, the results indicate that fractal metrics relating to the shape of vineyards, conifer patch size and the weighted area patch of shrub-scrub were stronger drivers of lower spatial scale habitat variables.

\section{DISCUSSION}

Most studies of hierarchical multi-scale effects on lotic systems analyse suites of environmental variables drawn from different spatial levels and attempt to identify the most relevant scales that lend structure to aquatic communities. Some authors have suggested that local factors, such as stream hydraulics, substrate, water chemistry, and riparian vegetation, contribute most to explaining species variance (Statzner et al., 1988; Ormerod et al., 1993; Sandin \& Johnson, 2004; Yuan \& Norton, 2004). Other studies have shown that higher scale landscape-level factors, such as land use/cover, geology, and surface area, or geographical factors, such as latitude and distance to river source, to be as important or even more relevant than the within-stream characteristics (Corkum, 1989; Lammert \& Allan, 1999; Richards et al., 1996; Roth et al., 1996, Hughes et al., 2008).

Table 6. Results of multiple non-parametric regressions from distance-based linear models between habitat quality (HQA sub indices; see Table 2), land use and fractal metrics, using Akaike's information criterion (AIC) to select the most significant group of variables from the sequential tests. Only the variables producing a more significant decrease on total AIC values are displayed. Resultados de la regresión múltiple no-paramétrica basada en modelos lineales de distancias entre la calidad del hábitat (índices HQA, ver Tabla 2), usos del suelo y métricas fractales del paisaje. Se utlizó el criterio de Akaike (AIC) para seleccionar el grupo de variables más significativo del test secuencial. Sólo se muestran las variables que produjeron una mayor reducción significativa en los valores del AIC.

\begin{tabular}{|c|c|c|c|}
\hline \multicolumn{4}{|c|}{ Model: with Fractal metrics; $R^{2}=0.992$} \\
\hline Variables selected (Best model 13 var.) & AIC & Pseudo-F & $\mathbf{P}$ \\
\hline Mean shape index of vineyard & 71.85 & 4.24 & 0.04 \\
\hline Patch size standard deviation of conifers & 69.86 & 3.66 & 0.03 \\
\hline Mean fractal dimension weighted area patch of shrubs & 68.48 & 2.78 & 0.05 \\
\hline Mean Fractal dimension area patch of shrubs & 68.36 & 1.51 & 0.21 \\
\hline \multicolumn{4}{|c|}{ Model: with Land use variables; $R^{2}=0.388$} \\
\hline Variables selected (Best model 3 var.) & AIC & Pseudo-F & $\mathbf{P}$ \\
\hline Conifer area & 73.88 & 2.05 & 0.13 \\
\hline Agriculture area & 73.75 & 1.83 & 0.16 \\
\hline Shrub area & 72.72 & 2.46 & 0.18 \\
\hline
\end{tabular}


The objectives of this study were to assess selected large scale variables, expressed as fractal metrics and as land-use variables, and to improve the level of correspondence between them and stream conditions as reflected by changes in the properties of the benthic macroinvertebrate community. The degree of dependence of local physical characteristics upon higher scale variables was also assessed. We followed the concept of Lowe et al. (2006), revising patterns and processes across multiple scales of stream-habitat organisation and giving emphasis to the fractal network structure of stream systems at the landscape level. Lowe et al. (2006) emphasised the need to understand how the spatial configuration of habitats within a network affects the flux of individuals, materials and energy. Our study design incorporated a set of fractal metrics quantifying the landscape patchiness and fragmentation. The effectiveness of fractal metrics and land-use variables in explaining the lower scale invertebrate and habitat descriptors varied but tended to indicate that fractal properties of the landscape were important drivers.

Several authors (Hawkins \& Vinson, 2000; Sandin \& Johson, 2000; Pyne et al., 2007) have recognised that high levels of heterogeneity within land classification types can complicate the detection of relationships between environmental attributes at large scales and local aquatic communities. By using a proximity method with a predefined area (circles with a $1 \mathrm{~km}$ radius around the study sites), we improved the applicability of the fractal metrics.

The nested MANOVA results indicated significant temporal and spatial variation within the benthic community composition and that the environmental drivers of change occur across a range of spatial scales. The temporal (interannual) difference in the levels of significance may be due to stochastic sampling effects or changes in habitat quality between the sampling campaigns that were not recorded. These differences may also be a result of the strong interannual variation that naturally occurs in rivers situated in the Mediterranean basin (Trigo et al., 2004).

The DISTLM analysis of the macroinvertebrate community structure and the hierarchically distributed factors showed that fractal metrics better explained the differences in the benthic invertebrate community composition between the river sites when compared with relative proportions of land use and indices of habitat quality derived at a lower spatial scale. RHS was performed only during the first sampling campaign, which limits the interpretation of results. However, the limitations of the reach-based RHS data for predicting the benthic macroinvertebrate distribution patterns is quite evident, supporting the findings of Cortes et al. (2008) and Cortes et al. (2009). Using Canonical Correspondence Analyses (CCA) to assess the relationship between macrophyte, macroinvertebrate and fish communities and a subset of non-intercorrelated RHS habitat variables, Cortes et al. (2009) found that levels of explained variance and the correlations between RHS data and the taxa were lowest for the benthic macroinvertebrates. However, a separate study on benthic macroinvertebrate fauna and hierarchically organised environmental and anthropogenic pressure descriptors showed that the reach and habitat level RHS data, which described riparian complexity, habitat and flow heterogeneity, were important drivers of change in the macroinvertebrate assemblages (Hughes et al, 2008). Erba et al. (2006) also identified strong correlation between selected macroinvertebrate metrics and RHS components.

Fractal landscape patterns are important spatial components that contribute to system diversity. The degree of heterogeneity in a landscape represents distinct structural and process units that result in the varied spatiotemporal distribution of aquatic assemblages and abiotic factors (Forman \& Godron, 1986, Berman, 2002). However, this conclusion was only partially supported by the lower levels of described variance resulting from the dbRDA ordination based on the fractal metrics. Although distinct grouping of sites and macroinvertebrate traits and metrics occurred in the fractal metric based dbRDA ordination space, the amount of variation explained was low and spread evenly among the fractal metrics. The results of the land-use-based dbRDA also indicated that gradients promoting change in the macroinvertebrate community were present, 
although other analyses did not strongly support these findings. According to Poff (1997), environmental filters operating at different scales influence the fitness of individuals, population productivity and community composition. This influence is the basis of the spatial hierarchy theory, which also states that higher scale attributes can constrain and predict lower scale attributes. Such constraints decrease as the number of intervening levels increases across the hierarchical network (Allen et al., 1987), reducing the ability to observe clear linkages between large-scale assessments and river biota.

The DISTLM regressions between the fractal metrics, land-use variables and physical characteristics at lower spatial scales helped to explain the hierarchical links and highlight the role of fractal descriptors in cause-effect relations between stream habitat and changes in land use. The results indicated that the fractal metrics were better predictors of river physical habitat quality than were the land-use variables, although this tendency was not pronounced.

We believe that the relationship between fractal metrics and the biota can be improved by including important landscape filters or more effective quantitative indicators of riparian quality (Poff, 1997). Riparian buffer strips reduce nutrient loads and soil erosion, and their spatial (i.e., fractal) pattern may affect their efficacy as nutrient sinks (Gergel et al., 2002). Sponseller et al. (2001) quantified land cover at five spatial scales (catchment level and four hierarchical scales describing the riparian layer at increasing distances upstream from the sampling site) and found that the most significant correlations between the macroinvertebrate indices and landcover patterns occurred at the lowest spatial scale where riparian vegetation directly influenced the lotic thermal regime. A comparison between riparian buffer zone properties and the entire watershed represents two extreme spatial scales for landscape scale indicator assessment. Landscape ecology has demonstrated the importance of both landscape properties and local site attributes in determining local ecological processes. This concept should be further explored to better identify the variety of scales, including fractal indica- tors that might be most meaningful in interpreting ecological patterns (Gergel et al., 2002).

We believe that the inclusion of other physical variables, such as variation in the hydrological regime, could further improve the association between the higher and lower level descriptors and the biota. Hydrological variation plays a critical role in habitat heterogeneity and ecosystem integrity, sustaining native biodiversity in catchments (Poff et al., 1997; Molnar et al., 2002). The occurrence of flood events, for example, drives temporal and spatial change in landform and river channel form (Poff et al., 1997; Molnar et al., 2002) and promotes the dispersal and recruitment of riparian seedlings (Dixon, 2003). These are factors that increase habitat heterogeneity and ultimately favour more trophically complex lotic communities (Pearson, Li \& Lamberti, 1992). However, catchment scale anthropogenic alterations of the hydrological regime also occur indirectly (e.g., changes in land use) and directly (e.g., water and sediment extraction, river engineering, floodplain destruction and dam construction). Changes in land use strongly affect riverine fractals by promoting upland erosion, increasing sediment input to lotic systems, channel erosion and flood peak intensity and frequency. The resultant increase in nutrient input subsequently affects primary productivity levels and the lotic food chain. Nutrient availability and stream metabolism have been shown to be highly sensitive to human land-use pressures (Schiller $e t$ al., 2008). Therefore, we believe that water quality and other local factors should also be included in the assessment of the relative contribution of environmental factors affecting aquatic communities and river function.

Finally, another important factor that influences the assessment of the links between land cover and stream condition is the innate covariance that occurs between natural and anthropogenic gradients (Allan, 2004a, Hughes et al., 2009). A simple example of such covariance is the occurrence of agricultural and urban areas in areas of river basins that are naturally less steep and more accessible. This phenomenon means that a great deal of the variance attributed to human factors will be affected by natural covariance. 
This study focused on anthropogenic changes in patterns of land use and their influence on stream biota and lower-scale descriptors of habitat. Changes in land cover are an essential driver of change in flow patterns and the flux of nutrients and sediments at successively lower scales, which influences the organisation of the different components of river biota and the circulation of materials.

\section{CONCLUSIONS}

This study supports a broader multiscale approach for characterising population and community dynamics and species-ecosystem linkages in streams, thereby providing a wider array of applications for management and indicators for conservation measures. The results emphasise the importance of describing large-scale features, particularly fractal descriptors of landscape composition and structure and their expression at a relevant scale, revealing their influence on aquatic systems without laborious analyses. The descriptors (metrics) of the interactions between the different landscape units (i.e., the fractal properties of the patches) are vital for identifying fluxes of materials toward the river. The patterns of these descriptors will help to predict localscale physical habitat characteristics, biological assemblages and facets of river function.

\section{REFERENCES}

AKAIKE, H. (1973). Information theory and an extension of the maximum likelihood principle. In: Second International Symposium on Information Theory. B.N. Petrov and F. Csake (eds.): 267-281. Budapest: Akademiai Kiado.

AKAIKE, H. (1974). A new look at the statistical model identification. IEEE Transactions on Automatic Control, AC-19, 716-723.

ALLAN, J. D. 2004a. Influence of land use and landscape setting on the ecological status of rivers. Limnetica, 23: 187-198.

ALLAN, J. D. 2004b. Landscapes and riverscapes: The influence of land use on stream ecosystems.
Annual Review of Ecology Evolution and Systematics, 35: 257-284.

ALLEN, T. F. H., R. V. O’NEILL \& T. W. HOCKSTRA. 1987. Interlevel relations in ecological research and management: some working principles from hierarchy theory. Journal of Applied Systems Analysis, 14: 63-79.

ANDERSON, M. J., R. N. GORLEY \& K. R. CLARKE. 2008. PERMANOVA+ for PRIMER: Guide to Software and Statistical Methods. Plymouth, U.K.: Primer-E Ltd.

BERMAN, C. 2002. Assessment of landscape characterization and classification methods. USDA Forest Service, No. PNW 99-9053-1-CA.

BONADA, N., C. ZAMORA MUÑOZ, M. RIERADEVALL \& N. PRAT. 2005. Ecological and historical filters constraining spatial caddisfly distribution in Mediterranean rivers. Freshwater Biology, 50: 81-797.

BOYERO, L. 2003. Multiscale patterns of spatial variation in stream macroinvertebrate communities. Ecological Research, 18: 365-379.

BUFFAGNI, A., C. CASALEGNO \& S. ERBA. 2009. Hydromorphology and land use at different spatial scales: expectations in a changing climate scenario for medium-sized rivers of the Western Italian Alps. Fundamental and Applied Ecology, 74: 7-25.

CORKUM, L. D. 1989. Patterns of benthic invertebrate assemblages in rivers of northwestern North America. Freshwater Biology, 21:191-205.

CORTES, R. M. V., S. G. P. VARANDAS S. J. HUGHES \& M. T. FERREIRA (2008). Combining habitat and biological characterization: Ecological validation of the river habitat survey. Limnetica, 27 (1): 39-56.

CORTES, R. M. V., S. J. HUGHES, S. G. P. VARANDAS, M. MAGALHÃES \& M. T. FERREIRA. 2009. Habitat variation at different scales and biotic linkages in lotic systems: consequences for monitorization. Aquatic Ecology, 43: 1107-1120.

DAVIES, N. M., R. H. NORRIS \& M. C. THOMS. 2000. Prediction and assessment of local stream habitat features using large-scale catchment characteristics. Freshwater Biology, 45: 343-369.

DIXON, M. 2003. Effects of flow pattern on riparian seedling recruitment on sandbars in the Wisconsin River, Wisconsin, U.S.A. Wetlands, 22: 125-139.

ERBA, S., A. C. BUFFANGI, N. HOLMES, M. O'HARE, P. SCARLETT \& A. STENICO. 2006. Preliminary testing of River Habitat Survey features 
for the aims of the WFD hydro-morphological assessment: an overview from the STAR Project. In: The Ecological Status of European Rivers: Evaluation and Intercalibration of Assessment Methods. M. T. Furse, D. Hering, K. Brabec, A. Buffagni, L. Sandin \& P. F. M. Verdonschot (eds.). Hydrobiologia, 566: 281-296

FRISSELL, C. A, W. J. LISS, C. E. WARREN \& M. D. HURLEY. 1986. A Hierarchical Framework for Stream Habitat Classification-Viewing Streams in a Watershed Context. Environmental Management, 10: 199-214.

GERGEL, S. E., M. G. TURNER, J. R. MILLER, J. M. MELACK \& E. H. STANLEY. 2002. Landscape indicators of human impacts to riverine systems. Aquatic Sciences, 64:118-128.

HAWKINS, C. P. \& M. R. VINSON. 2000. Weak correspondence between landscape classifications and stream invertebrate assemblages: implications for bioassessment. Journal of the North American Benthological Society, 19:501-517.

HEINO, J., P. LOUHI \& T. MUOTKA. 2004. Identifying the scales of variability in stream macroinvertebrate abundance, functional composition and assemblage structure. Freshwater Biology, 49: 230-1239.

HEINO, J., T. MUOTKA, R. PAAVOLA, H. HAMALAINEN \& E. KOSKENNIEMI. 2002. Correspondence between regional delineations and spatial patterns in macroinvertebrate assemblages of boreal headwater streams. Journal of the North American Benthological Society, 21: 397-413.

HERING, D., C. FELD, O.MOOG \& T. OFENBÖCK 2006a. Cook book for the development of a Multimetric Index for biological condition of aquatic ecosystems: experiences from the European AQEM and STAR projects and related initiatives. Hydrobiologia, 566, 311-324.

HERING, D., R. JOHNSON, S. KRAMM, S. SCHMUTZ, K. SZOSZKIEWICZ \& P. VERDONSCHOT 2006c. Assessment of European streams with diatoms, macrophytes, macroinvertebrates and fish: a comparative metric based analysis of organism response to stress. Freshwater Biology, 51, 1757-1785.

FELD, C. \& D. HERING 2007. Community structure or function: effects of environmental stress on benthic macroinvertebrates at different spatial scales. Freshwater Biology, 52, 1380-1399

FORMAN, R. T. T. \& M. GODRON. 1986. Landscape Ecology. John Wiley and Sons, New York. 640 pp.
FURSE, M. T., D. HERING, K. BRABEC, A. BUFFAGNI, L. SANDIN \& P. F. M. VERDENSCHOT. 2006. The ecological status of European rivers: evaluation and intercalibration of assessment methods. Hydrobiologia, 566: 1-2.

HUGHES, S. J., M. T. FERREIRA, R. M. V. CORTES. 2008. Hierarchical spatial patterns and drivers of change in benthic macroinvertebrate communities in an intermittent Mediterranean river. Aquatic Conservation: Marine and Freshwater Ecosystems, 18: 742-760.

HUGHES, S. J., J. M. SANTOS, M. T. FERREIRA, R. CARAÇA, A. M. MENDES 2009. Ecological assessment of an intermittent Mediterranean river using community structure and function: evaluating the role of different organism groups. Freshwater Biology, 54: 2383-2400

JOY, M. K. \& R. G. DEATH. 2004. Predictive modelling and spatial mapping of freshwater fish and decapod assemblages: an integrated GIS and neural network approach. Freshwater Biology, 49: 1036-1052.

LAMMERT, M. \& J. D. ALLAN. 1999. Environmental Auditing: assessing biotic integrity of streams: Effects of scale in measuring the influence of land use/cover and habitat structure on fish and macroinvertebrates. Environmental Management, 23: 257-270.

LAMOUROUX, N., S. DOLÉDEC \& S. GAYRAUD 2004. Biological traits of stream macroinvertebrate communities: effects of microhabitat, reach, and basin filters Journal of the North American Benthological Society, 23(3): 449-466

LOWE, W. H., G. E. LIKENS \& M. E. POWER. 2006. Linking Scales in Stream Ecology. BioScience, 55: 591-597.

MÉRIGOUX, S., S. DOLÉDEC. 2004. Hydraulic requirements of stream communities: a case study on invertebrates. Freshwater Biology, 49: 600-613.

MOLNAR, P., P. BURLANDO \& W. RUF. 2002. Integrated Assessment of riverine landscape dynamics. Aquatic Sciences, 64: 129-140.

MUNNÉ, A., N. PRAT, C. SOLA, N. BONADA \& M. RIERADEVALL. 2003. A simple field method for assessing the ecological quality of riparian habitat in rivers and streams: QBR index. Aquatic Conservation: Marine and Freshwater Ecosystems, 13: 147-163

ORMEROD, S. J., S. D. RUNDLE, E. C. LLOYD \& A. A. DOUGLAS. 1993. The influence of riparian 
management on the habitat structure and macroinvertebrate communities of upland streams draining plantation forests. Journal of Applied Ecology, 30: $13-24$.

PARSONS, M. \& M. C. THOMS. 2007. Hierarchical patterns of physical-biological associations in river ecosystems. Geomorphology, 89: 127-146.

PEARSON, T. N., H. W. LI \& G. A. LAMBERTI. 1992. Influence of habitat complexity on resistance to flooding and resilience of stream fish assemblages. Transactions of the American Fisheries Society, 121, 427-436.

POFF, N. L. 1997. Landscape filters and species traits: Towards mechanistic understanding and prediction in stream ecology. Journal of the North American Benthological Society, 16: 391-409.

POFF, N. J. D. ALLAN, M. B. BAIN, J. R. KARR, K. L. PRESTEGAARD, B. D. RICHTER, R. E. SPARKS \& J. C. STROMBERG. 1997. The natural flow regime: A paradigm for river conservation and restoration. BioScience, 47: 769-784.

PYNE, M. L., R. B. RADER \& W. F. CHRISTENSEN. 2007. Predicting local biological characteristics in streams: a comparison of landscape classifications. Freshwater Biology, 52: 1302-1321.

RAVEN, P. J., P. FOX, M. EVERARD, N. T. H. HOLMES, F. H. DAWSON. 1997. River Habitat Survey: a new system for classifying rivers according to their habitat quality. In: Freshwater quality: defining the indefinable? Boon, P. J., Howell, D. L. (eds.): 215-234. The Stationery Office, Edinburgh.

RAVEN, P. J., N. T. H. HOLMES, F. H. DAWSON, P. FOX, M. EVERARD, I. R. FOZZARD \& K. J. ROUEN. 1998. River habitat quality: the physical character of rivers and streams in the UK and the Isle of Man. River Habitat Survey report no. 2, Environment Agency, Bristol. 86 pp.

RAVEN, P. J., N. T. H. HOLMES, P. CHARRIER, F. H. DAWSON, M. NAURA \& P. J. BOON. 2002. Towards a harmonized approach for hydromorphological assessment of rivers in Europe: a qualitative comparison of three survey methods. Aquatic Conservation: Marine and Freshwater Ecosystems, 12: 405-424.

RICHARDS, C., L. B. JOHNSON \& G. E. HOST 1996. Landscape-scale influences on stream habi- tats and biota. Canadian Journal of Fisheries and Aquatic Sciences, 53: 295-311.

ROTH, N. E., J. D. ALLAN \& D. L. ERICKSON. 1996. Landscape influences on stream biotic integrity assessed at multiple spatial scales. Landscape Ecology, 11: 141-156.

SANDIN, L. 2009. The relationship between landuse, hydromorphology and river biota at different spatial and temporal scales: a synthesis of seven case studies. Fundamental and Applied Ecology, 174: $1-5$.

SANDIN, L. \& R. K. JOHNSON. 2000. Ecoregions and benthic macroinvertebrate assemblages of Swedish streams: Journal of the North American Benthological Society, 19: 462-474.

SANDIN, L. \& R. K. JOHNSON. 2004. Local, landscape and regional factors structuring benthic macroinvertebrate assemblages in Swedish streams. Landscape Ecology, 19: 501-514.

SCHILLER, D. V., E. MARTÍ, J. L. RIERA, M. RIBOT, J. C. MARKS \& F. SABATER. 2008. Influence of land use on stream ecosystem function in a Mediterranean catchment. Freshwater Biology, 53: 2600-2612.

SPONSELLER, R. A., E. F. BENFIELD \& H. M. VALLET. 2001. Relationships between land use, spatial scale and stream macroinvertebrate communities. Freshwater Biology, 46: 1409-1424.

STATZNER, B., J. A. GORE \& V. H. RESH. 1988. Hydraulic stream ecology: observed patterns and potential applications. Journal of the North American Benthological Society, 7: 307-360.

TRIGO, R. M., D. POZO-VÁZQUEZ, T. J. OSBORN, Y. CASTRO-DIÉZ, S. GÁMIZ-FORTIS \& M. J. ESTEBAN-PARRA, 2004. North Atlantic Oscillation Influence on precipitation, river flow and water resources in the Iberian Peninsula. International Journal of Climatology, 24: 925-944.

VARANDAS, S. G. \& R. M. V. CORTES. 2010. Evaluating macroinvertebrate biological metrics for ecological assessment of streams in northern Portugal. Environmental Monitoring and Assessment, 166: 201-221.

YUAN, L. \& S. B. NORTON. 2004. Assessing the relative severity of stressors at a watershed scale. Environmental Monitoring and Assessment, 98: 323-349. 